\title{
NATURAL AND INTENTIONAL STRUCTURES OF SEXUALITY
}

My recent reading of Le deuxième sexe, ${ }^{1}$ a good fifty years after its publication, has been a source of pleasure and astonishment. Pleasure mainly because of Simone de Beauvoir's French, which pours out page after page, four or five semicolons to each sentence, with a facility and a command that recall other monuments of style, Proust for example, or - closer to home and unsurprisingly enough - Sartre.

Astonishment mainly because of how contemporary de Beauvoir still is, how much I found I could still learn from her. To be sure her ethnographic base, as it were, the daughters of the French bourgeoisie, was limited and not entirely representative of the condition of women in general - and yet in spite of the dated character of some of her evidence, and her tendency to overgeneralize, her insights seem as much on target now as ever.

Fresh from this rich experience, the one thing that stands out in my memory, and the point from which I will begin, is the very last word in the book. As I closed it I thought to myself: that cannot possibly have been an accident. The first words of the first chapter in the first volume, after the introduction, are "La femme?" (sic). But the last word of the last chapter of the second volume is "fraternité." Here is something else astonishing: the inscription of one of the first great manifestoes of feminism under the sign of brotherhood. It is just possible, I suppose, that in 1949 even de Beauvoir was insensitive to the pervasive sexism of language. She certainly accepted and practiced without comment the use of the masculine form for otherwise ungendered references, but this is less remarkable in French than in English, since linguistic gender regularly crosses other gender assignments. (It often comes as a surprise to English-speaking students of French that, once having referred to someone, even a male, as a "person," further references have to make him feminine: "il faut dire, de la personne qui est en train d'écrire cet article, qu'elle porte le nom de Peter Caws.") But after 1000 pages of feminist affirmation it is hard to believe that "fraternité" just slipped under the radar.

\footnotetext{
${ }^{1}$ Simone de Beauvoir, Le deuxième sexe (Paris: Gallimard, 1949. Cited as LDS; references are to the Folio edition).
} 
Not too many people seem to share my astonishment - plenty of feminists have taken de Beauvoir to task for suggesting that women should be more like men (which I don't think she does) but hardly any of them dwell on the anchor position of this reference to brotherhood. Eleanor Kuykendall devotes some sensitive analysis to the last sentence and remarks on the unavailability of a feminine counterpart to "fraternity" in French in 1949, though she sees that in context "sorority" would have been no help. ${ }^{2}$ Adopting a form of the principle of charity - crediting de Beauvoir with knowing what she was doing - how might we read "fraternité" here? A couple of possibilities come to mind. One is that in claiming fraternity for women and men together de Beauvoir is subtly underlining the ambiguity that is her trademark. This would accord well with that ironical question mark at the beginning: "La femme?" Human beings - anatomy apart - are not wholly or essentially masculine or feminine, and the kind of cognitive dissonance that this last word provokes may help to destabilize the idea that they are.

The second possibility is perhaps more subtle. De Beauvoir is always comparing the experiences of young women with that of their brothers, and if we look at the relations between men and women as a kind of sibling rivalry writ large we might consider the insistence on brotherhood as staking the claim that sisters should have as much as, and be treated in the same way as, their brothers - not that women demand more than what men already have (their fraternity) and not that they demand something different (which might perhaps be sorority), but that they demand exact parity in a world where the basis for it is already in place - only in such a way as, up to this point, to exclude them. It should be noted that an insistence on fraternity does not in any way deny the possibility of sorority - women can still be women, indeed in many places de Beauvoir insists on this ("ce serait ... une mutilation de répudier son sexe. .... Renoncer à sa féminité, c'est renoncer à une part de son humanité" (LDS II:601)). (The question rather is how men can still speak of themselves as men; the language puts them in an awkward position, because having let the masculine become the universal they can no longer count on its reference to the masculine as such.)

${ }^{2}$ Eleanor Kuykendall, "Simone de Beauvoir and Two Kinds of Ambivalence in Action," in Iris Young and Jeffner Allen, eds., The Thinking Muse (Bloomington: University of Indiana Press, 1989), pp. 35-50. 
The end of the book is interesting, however, not only for its final word. De Beauvoir quotes Marx's aphoristic comment that the relation between man and woman is the "immediate, natural, and necessary" relation between man and man. She continues the citation from Marx:

“... le rapport de l'homme à la femme est le rapport le plus naturel de l'être humain à l'être humain. Il s'y montre donc jusqu'à quel point le comportement naturel de l'homme est devenu humain ou jusqu'à quel point l'être humain est devenu son être naturel, jusqu'à quel point sa nature humaine est devenue sa nature."

On ne saurait mieux dire. C'est au sein du monde donné qu'il appartient à l'homme de faire triompher le règne de la liberté; pour remporter cette suprème victoire il est entre autres nécessaires que par-delà leurs différenciations naturelles hommes et femmes affirment sans équivoque leur fraternité (LDS II:663).

What is striking in this passage is her importation from Marx of the dialectic of nature and humanity. That the relation between the sexes should be the most natural relation between human beings does not mean that it is, as such (or as yet), a human relation. We want to become human - but we want being human to be natural to us. Yet for de Beauvoir the affirmation of brotherhood has to take place beyond nature, on the other side of the natural ("par-delà leurs différenciations naturelles" - the English translation here has "by and through their natural differentiation," 3 which overlooks de Beauvoir's plural and suggests that brotherhood will emerge from difference, which she quite clearly thinks it won't). Everything is not quite clear here - perhaps "on ne saurait mieux dire" is more enthusiastic than considered. At all events it seems worth looking a little more closely at the relations between the natural and the human (or the cultural, or as I shall want to say the intentional) as they bear on the relations between the sexes. That is what I shall set out to do in this paper.

${ }^{3}$ Simone de Beauvoir, tr. and ed. H. M. Parshley, The Second Sex (New York: Vintage Books, 1974 [Knopf, 1953]), p. 814. 
In doing so I shall be translating some of de Beauvoir's concepts and concerns into an idiom of my own, and approaching the subject afresh from a starting-point as presuppositionless as I can make it. My approach is not that of feminism as such, nor of existentialism, nor of phenomenology, but rather of the human sciences considered as complementary to the natural sciences in the rigorous formulation of human knowledge. The goal of the sciences in general, we might say, is object constancy across knowing subjects (together, of course, with a body of confirmed propositions about these objects and their interrelations). In the natural sciences object constancy is a relatively simple matter, not because the objects of the natural sciences are in themselves simple (those sciences have to be complicated enough to deal with the real complexities of nature) but because, other things being equal, they are accessible to repeated and eventually systematic observation; they are within limits constant across perceiving subjects, which simplifies the task of establishing their constancy across knowing ones. (I omit here all considerations of unobservable or inferred objects, the effect of experimentation on the object, etc., as irrelevant to my concerns in this paper.) We take the objects of the natural sciences to be as they are independently of human intention or interest. To put this another way, it is plausible to entertain with respect to them what $I$ call a "realist hypothesis." The objects of the human sciences, on the other hand, come into being only because of human intention and interest, and in many cases have no perceptual presence in the world. I call them, following the example of some proto-phenomenologists like Brentano, intentional objects. Those that do present perceptually have either been selected as objects of human interest, or constructed by technology in one form or other to serve human interests; they have the object constancy of any perceptual object, but it is not the perceptual object as such that the human sciences wish to investigate - it is the use, the meaning, the significance of the object that is at stake. And these uses, meanings and significances can be discussed independently of their embodiment in perceptual objects. The power of the law, to take a representative example, is embodied in part in courtrooms, robes, and gavels, but those are not the objects we study when we study the law: tort, equity, precedent, interpretation are not so easily found in the world, and giving them object constancy across knowing subjects is the task of legal studies, which belong comfortably under the rubric of the human sciences.

It is well known that Marx wanted to produce a natural science of the human, of history and economics, aiming to do for the social 
what Darwin had done for the biological. Ever since the recommendation in Book VI of Mill's great Science of Logic, that the moral sciences should imitate the natural sciences, the attempt to assimilate intentional objects to perceptual ones has dogged the development of the complementary sciences that I am calling human. It is an attempt that is doomed to failure. The objects of the human sciences are characteristically relational, in that their recognition as the objects they are depends on the relations that constitute them and into which they enter. Clusters of relations define structures (an idea familiar to de Beauvoir, who knew and admired Lévi-Strauss). We may speak of natural structures when physical elements are externally related to one another in determinate ways - the cell structures of plants, the chemical structures of compounds etc., structures that we take to be given and discovered. But the structures of the family, of the novel, of tragedy, of political institutions etc. are not given naturally, they are created and sustained by human intentionality. The relations that constitute them are not given with the elements they relate but the elements are held in place, as related, from the point of view of intending subjects. In the end we may say they belong to culture, broadly speaking, though as we shall see we need levels of intentional structure that are not yet fully cultural.

All cultural structures are intentional, in that they were once at least the (possibly unforeseen) consequences of intentional acts of communication or creation or judgment, etc. They may come to us as quasi-natural because we encounter them and their embodiments in a world also populated with natural structures: so history and language and religion are taken by many people to be as objectively real as trees and mountains and rivers. Deconstructing that sense of immutable givenness is one of the tasks of the human sciences. For the objects of the human sciences a realist hypothesis is not plausible; their apparent objectivity has to be accounted for in other ways. A particular case of this apparent objectivity is the sexism that has been built over time into the social structures of so many cultures - including our own - where it has for so long appeared natural for women to occupy subordinate positions, to be at the service of men, etc. But not all intentional structures are cultural - if they were, there would be no changing culture. Intentionality has a creative side, and it must be possible for an individual, or a couple, or a small group, to generate intentional structures that are at odds with those of their culture - to construct new proto-cultures in which, for example, the relations between women and men are newly configured. 
One more terminological point and I will have done with this preliminary treatment of the human sciences. Intentional and cultural structures are internalized and sustained by individuals: each individual has a whole language, a whole family or other institutional structure, a whole history (his or her own, and that of the social group or discipline to which he or she belongs), and so on. These may of course be radically incomplete or even wrong (judged by the structures internalized by the others, whether a majority or a small group of standard-bearers), but there will usually come to be a convergence, a consensus. At that point the individual may forget that the structure in question is his or her own, and consider it to be lodged in the group. But its being his or her own is what enables the group to survive; the group would cease to exist as such if all its members relied on the others to sustain it. The process of the internalization of structure I call, for reasons sufficiently transparent, instruction, in-struction, and I distinguish a number of stages of instruction which I will enumerate without much comment.

Over the life-cycle the structuring process begins in utero with genetic and epigenetic instruction, what we sometimes think of as the "hard-wired" part of mental structure. After birth, experiential instruction lays down the pattern of interactions with the external world and provides a first representation of it, and later on its more active variant that I call experimental instruction refines these by a process of manipulation and testing of the local environment. But by far the greatest proportion of the final structure is put in place by cultural instruction, beginning with the acquisition of language and followed by all the complex inherited structures of behavior and society that are communicated to each generation with the authority of the preceding one. This is where instruction in the conventional sense belongs, as practiced in educational institutions at all levels, but that is only a part of the story. Formal instruction tends to be vertical, from teacher to learner, but there is obviously also a vast network of what we might call horizontal instruction, from peers, from the media, from the artifacts of the cultural environment. Finally there can be (though there often isn't) a neglected but overwhelmingly important form of instruction that I call reflexive or autonomic instruction, which occurs when the subject takes itself and its structures in hand and works them over with an eye to interconnections, coherence, creative possibilities, etc. 
With this apparatus in hand we are in a position to look at Simone de Beauvoir's enterprise in Le deuxième sexe, to see if any light can be thrown on it from the theoretical perspective of the human sciences. I shall work with the simple opposition between natural structures and intentional ones, remembering that cultural structures are a special, if dominant, case of the latter. It may be helpful to give a neutral example of the way in which the natural and intentional articulate in our experience of the world and in the emergence of culture. Imagine a primitive family living in an environment rich in natural structures, among which are caves. The caves are not, let us suppose, endowed with any special significance in the beginning; but the family is in need of shelter and begins to look at various caves with an eye to their suitability - whether they are dry, have good overhangs, will allow fires without smoking up, are free of dangerous fauna etc. They find a suitable cave and move in. The cave now becomes a natural structure with an intentional overlay: it is not just a cave, it is a cave dwelling. The intentional object "cave dwelling," no longer tied to any particular natural structure, now comes into being as an element of the family's proto-culture - the next generation when it sets up is own ménage will have that object as a standard for the choice of its new cave. Meanwhile no doubt the original cave dwelling has been improved by means of primitive technology, so that the old natural structure begins to be left behind. Finally, let us suppose, the purely intentional object "home" emerges; its structure will have elements of affect, of kinship, of normativity, it will acquire cultural accretions (perhaps as in Robert Frost "when you have to go there they have to take you in"), and it will be independent of any actual embodiment, whether in cave, castle, trailer, condominium, or whatever. As this illustration shows, natural structures can be doubled by intentional ones (the cave is still a cave but it is also a dwelling), and this doubling may lead to the budding off, as it were, of purely intentional structures not directly tied to any natural one. But intentional structures do not need to take their departure from natural ones, and in the later stages of instruction and human creativity this is rare: everything is intentional.

Before proceeding let me clear up one small further point. I shall be relying heavily on the distinction between natural and intentional, but it should be noted that that distinction is already intentional, not natural. In one way this is unremarkable, since language itself is an intentional structure and all linguistic distinctions are intentional. However we need to be clear in this particular case because linguistic practices can be descriptive or normative, and the 
term "natural" often has normative connotations (as for example when it is used in opposition to "unnatural" in discussing deviant sexual practices). I shall mean by natural just what I specified above: having come about without purposeful human intervention; and as I use it the term will carry no normative weight.

We may now ask the question: what are the natural structures of sexuality? In dealing with de Beauvoir it will be clear that where sexuality is concerned my distinction between the natural and the intentional will map roughly on to her distinction between the anatomical and the social or situational. But that is too simple: anatomy is physical structure but that is not the only kind of natural structure. I shall distinguish at the level of the natural at least two kinds of structure, which I will call on the one hand physical and on the other behavioral. Let us restrict attention at first to neonates and very young children, young enough so that structures of intentionality have not yet been activated and cultural instruction has not yet begun. (A case might be made that there is no such window of the purely natural, that newborns are capable of meaningful action and that cultural instruction begins subliminally in utero, but for the moment I will overlook these possibilities.) The natural physical structures at this stage will mainly consist of the genitalia, whether male or female or (as in about one birth out of 2000) intersexual. These things are as they are and nobody arranged them that way, so they count as natural by my criterion; intersex genitalia may be thought unnatural (until recently at least they were regularly adjusted by surgery) but they aren't unnatural, they are just statistically infrequent. What of natural behavioral structures? Well, these again are whatever they are, whatever the baby or small child does with his or her own genitalia or those of any other child who happens to be around. Freud knew that infants are great explorers of their own bodies, that they will cheerfully suck or push or poke anything within reach, genital or otherwise, and in fact we might say that the natural behavioral structure of sexuality at this first stage is what he called "polymorphous perversity." This is unfortunately named, at least as to its second element. Perverse suggests deviation from a norm, but there are no norms in nature - norms are essentially intentional and represent the judgments of knowing subjects.

There is a second stage in the development of the natural physical structures of sexuality, which makes its appearance at puberty. Again the standard features are obvious enough: some body hair in both sexes; in men facial hair also, and the lowering of the voice, and 
nocturnal emissions; in women menstruation and the emergence of breasts. There may be indirect cultural influences on some of this - for example the progressively earlier occurrence of menarche among young women in some societies, though this may have more to do with nutrition than anything else - but by and large bodies are still doing what their genes tell them to. Is there a corresponding second stage in the development of natural behavioral structures? The difficulty here is that, except in cases of severe retardation, all behavior has long since been (in principle) under intentional surveillance if not always control. Human beings are taught that they are responsible for their behavior, and from toilet training on they habitually monitor their bodily actions with this responsibility in mind. No doubt there are massive exceptions to this rule, some arising from ignorance and some from pathology, and no doubt it was not always the case. Before culture there would have been natural behavioral structures of sexuality at this second stage - if untaught individuals had not spontaneously discovered copulation the race would have died out. This spontaneous discovery may still take place, but it must require a considerable degree of naivete or ignorance; most children are well aware of the major features of the physiology of sex well before they come to engage in it. The one candidate for a natural behavioral structure of sexuality at puberty is probably masturbation, a relic of polymorphous perversity which is regularly rediscovered and can be hidden from social view. But it is well known what alarm this practice provokes among the more conservative guardians of the culture, and until recently at least it was the rare adolescent who could escape its association with moral weakness and guilt.

De Beauvoir makes a great deal of the asymmetry of the sexes at this stage. She claims that the transition through it is easier for men than for women:

... pour l'homme le passage de la sexualité infantile à la maturité est relativement simple: il y a objectivation du plaisir érotique qui au lieu d'être réalisé dans sa présence immanente est intentionné sur un être transcendant. .... L'érotisme de la femme est beaucoup plus complexe et il reflète la complexité de la situation féminine (LDS II:147-148).

Men experience only changes in degree, she thinks, but for women menstruation and the useless excrescence of the breasts are changes in kind. And they are changes for which many of her informants were ill- 
prepared, as indeed they were for sexual relations with men, so that the changes were experienced passively. This question of passivity and activity is of the first importance. I said just now that by the time of puberty children are accustomed to monitoring their own bodily actions. According to my view of the matter it is necessary to distinguish between actions and acts, an action being something the body does, an act being the appropriation of an action by the agent as his or her own. Such appropriation is, in the language of my earlier discussion, precisely the doubling of a physical structure by an intentional one, so that by the time the subject becomes an agent the purely physical is necessarily transcended. This principle is of great theoretical generality - I claim for example that every bodily act at a given level of emergence corresponds to a possible action at the next lower level, and its appropriation as an act is a case of what I call selective "lettinghappen." A child who is used to this kind of monitoring and control will be alarmed if his or her body does something unexpected on its own, if something happens that has not been let happen in this way. Because the monitoring and control are associated, as I suggested earlier, with the concept of responsibility, the child will feel anxious or even guilty about it. In the case of the boy experiencing his first nocturnal emission, for example, he may if he has not been forewarned worry that the sort of incontinence he learned to control as an infant has unaccountably re-surfaced in adolescence. Here I think, against de Beauvoir, that the transition may be more difficult for unprepared men than for unprepared women - however alarming the first menses may be, at least bleeding is not one of the things the young girl will have been expected to control. The balance swings in the other direction, though, when we factor in the frequent experience of the unwanted and traumatizing sexual initiation of women, of which de Beauvoir has massive anecdotal evidence. Matters are not helped by the fact that in more traditional societies this traumatic event is often legitimized by marriage. We might say that for women there is all too frequently an encounter with a "natural" behavioral structure of sexuality at this stage, in which Nature appears as hostile and threatening. The behavior in question, however, is not their own but that of the men to whom their culture has delivered them up. Rape, the statistics about which even in our own society are alarming, is a part of this story but is of course not limited to the emergence of second-stage structures of sexuality.

For women, and for women only, there is a third stage in the emergence of natural physical structures of sexuality. For a man, participation in an effective act of reproduction is, physiologically, just 
another episode of what he has been doing all along since puberty. It is, mercifully, not the case that all sexual encounters lead to fertilization (though it would be interesting to speculate on how the relations between the sexes would have evolved if this had been, and been known to be, the case - things might be worse, but they might conceivably have gotten better sooner). But when fertilization does occur, nature takes over once again: nobody planned the sequence of gestation, parturition, and lactation, and although obstetrical technology can modify the process its basic unfolding fully satisfies my definition of the natural. Here however my theory of acting as letting-happen, and of acts as the appropriation of actions as the agent's own, can help to modify de Beauvoir's rather dour views of the pregnant woman and nursing mother as victims. They may of course be victims, if fertilized against their wills or forced by oppressive laws, secular or religious, to carry unwanted fetuses to term. But when de Beauvoir says:

La femme qui engendre ne connaît donc pas l'orgueil de la création; elle se sent le jouet passif des forces obscures, et le douloureux accouchement est un accident inutile ou même importun. ... [E]ngendrer, allaiter ne sont pas des activités, ce sont des fonctions naturelles; aucun projet n'y est engagé; c'est pourquoi la femme n'y trouve pas le motif d'une affirmation hautaine de son existence; elle subit passivement son destin biologique (LDS I:112),

she overlooks the possibility that a woman might wish and freely decide to appropriate just these actions of her body - actions of which a man's body is incapable - as her acts. ${ }^{4}$ And creative acts at that. The theory I have been advancing would claim that any form of physical creation, artistic, musical etc., is just such an appropriation - artists are artists, and musicians musicians, because of things their bodies can do that other people's can't and because they know how to appropriate and cultivate these talents. If this suggests that every woman who brings a child to term, by way of a conscious appropriation of the capacities of

\footnotetext{
${ }^{4}$ Virginia Held makes a similar point when she says that to reduce giving birth to a merely natural process denies "the full humanity of the woman who gives birth" (Virginia Held, Feminist Morality: Transforming Culture, Society and Politics [Chicago: University of Chicago Press, 1993], p. 125).
} 
her body, achieves in her own domain something like what artists and musicians achieve in theirs - well, that is perhaps one of the rewards of being a woman. The analogy may seem stretched, but there is far more activity involved in a healthy pregnancy than sitting around as the plaything of obscure forces, and bearing and raising children can certainly be done well or badly, even very well or very badly. For what it is worth one pediatrician and psychiatrist at least has written on the child as a work of art. ${ }^{5}$

So much, then, for what I am calling the natural structures of sexuality. (I should perhaps not leave the topic behind without acknowledging a fourth stage, again unique to women, namely menopause, to which de Beauvoir devotes a brief chapter which is, however, more about the social consequences of aging than about the physiology of sexuality.) Let me recapitulate: in the very early years there seem to be natural physical structures and also natural behavioral structures of sexuality, but in humans the "naturalness" of sexual behavior, in any pure form, gets left behind rather quickly because of the conscious attention children are required by culture to pay to their bodily functions. Sexuality is one of those domains in which natural structures are eventually doubled by intentional ones, to such an extent that where behavior is concerned it is difficult to recover the natural. The developing physical structures are experienced through a thick accretion of cultural prejudices and expectations, and de Beauvoir devotes much of her book to an expert dissection of these. The overlay of intentionality over nature is of course inevitable for a subject with any degree of self-awareness, and in the form of self-knowledge it can be entirely benign. That indeed is the first step to liberation. I mentioned above the trauma of adolescents who have not been forewarned about physiological changes at puberty; the trauma could be almost entirely eliminated, and in these days of explicit sexual education no doubt often is, by early instruction - "almost entirely" because there may be a residue of affect that no amount of cognitive preparation can overcome. But de Beauvoir pays strikingly little attention to the affective as such, and this represents a lacuna in her work.

It would be tempting to add a category to the natural structures of sexuality to cover the emotional haplessness which for many people

\footnotetext{
${ }^{5}$ Bennett Olshaker, M.D., The Child as a Work of Art (Washington: Marko Books, 1975).
} 
accompanies the stirrings of the sexual life, especially in relation to possible partners, but I will forgo the attempt, partly because it would be a distraction and partly because the question whether any human emotion beyond the infantile can be wholly natural is a very difficult one. Certainly a great many emotions are learned: teenagers who swoon over rock stars are greatly influenced by the fact that other teenagers do the same, that they can describe to one another and discuss among themselves their idols and their feelings, etc. And yet there may be a spontaneous natural emotion under it all, and a complicated hormonal reaction under that. De Beauvoir does discuss the emotion, if it can be called that, of modesty or shame, and agrees that its origin is mixed:

Sa pudeur est en partie apprise: mais elle a aussi des racines profondes; hommes et femmes connaissent tous la honte de leur chair; dans sa pure présence immobile, son immanence injustifiée, la chair existe sous le regard d'autrui comme l'absurde contingence de la facticité et cependant elle est soimême: on veut l'empêcher d'exister pour autrui; on veut la nier (LDS II:159).

But her stress, like Sartre's, is on emotions produced by the realization of one's vulnerability to others, by the "look."

In his Esquisse d'une théorie des émotions Sartre concludes that emotion is a mode of intentionality, a way of experiencing the world having very much the structure I have been suggesting, in which intentionality is as it were laid over a more basic, perhaps a more natural, structure. Emotion can thus be seen as a special case of a more general category of intentional attitudes and projections. I turn now toward the broader question of the intentional structures of sexuality, under which will fall those emotions characteristic of the sexual life. We have seen that the physical changes accompanying the stages of sexuality can be experienced as alarming, but they can also be experienced with pride or excitement. In either case they are experienced by an individual subject, necessarily embodied. My embodiment conditions my subjectivity, but I have some choice in the way I live this conditioning: I may feel subjected to it as an imposition or I may freely be the subject of it as an appropriation - that is, I may choose in respect of it the status of a patient or of an agent. Two caveats: first, even though I take myself to have this choice, I do not always manage, in practice, to make it wisely or effectively; second, a 
great many people (in particular many of those whose stories are recounted by de Beauvoir) do not know they have it. On the exercise of this choice depends the possibility of freedom. Sartre once made a scathing dismissal of a sociology that assumed the subjection of individual lives to determinate social conditions, saying in effect: I thought I was dealing with sociologists - my mistake, it turns out they were entomologists. Unfortunately most human lives are lived in a state of subjection to social conditions - not just economic constraints but psychological, political, religious and moral expectations that do not spring from the individual's conviction or even agreement. Many people will not even be aware of them as constraints - they are part of the normal background - but they may come to be experienced as external and oppressive (or repressive). It was the message of existentialism, to which de Beauvoir remains on the whole faithful in $L e$ deuxième sexe, that the individual need not accept this conditioning without question or challenge. She realized more fully than Sartre did, at least in his early work, how long and how daunting the road may be from the abstract freedom to make a project against social conditioning to the realization of any effective liberation. But the fact that in spite of obstacles the freedom in question is a constitutive feature of existential subjectivity must be the starting-point for any consideration of lived intentional structures. Not to start there but on some higher level where constraints are already built in is to give up part of the battle before it is engaged.

I place myself, then, in the position of an embodied subject the facticity of whose situation includes the natural and early behavioral structures of sexuality we have been considering, but who is free to make any intentional moves he likes consistently with his project - and moreover to change his project if that is what he freely chooses. I say "he" here because at this stage of the argument I can no longer deal with the structures in question from the detached position of the naturalscientific observer, but must occupy a first-person stance. My embodiment happens to be male and the conventions of the language in which I write require me to use the masculine form. Note that this is one of the social constraints from which the existential subject is theoretically free - but to exercise my freedom in that particular way would carry a cost, in terms of reduced intelligibility, inconsistent with my free project of communicating these ideas. So I use "he" even though the binary opposition of "he" and "she" excludes our intersex colleagues. Actually English carries fewer constraints than some other languages in this regard - I can always preserve gender anonymity by 
using the first person, since adjectives do not give the game away in English, though they do in French. ${ }^{6}$

I accept the conventions of language that require me to use the masculine form, because, as I say, my embodiment happens to be male. What is the force of this "happens to be"? I stress it because the transcendental subject that I am encounters its embodiment and learns that it is male, but is itself not gendered. It learns a lot of other things about its embodiment, about age, habitus, race etc., but again the transcendental subject is (as I see it and have argued elsewhere) atemporal, presuppositionless, classless. It is self-aware and it has the powers of apposition and intentionality, and it has at its disposal (although it does not know this at first, indeed may never know it in any detail) a neurophysiological platform that will run its functions of awareness and intentionality, but that is all - the rest comes later. Where then does my self-aware, intending subjectivity originally stand in relation to sexuality? What kinds of intentional structure will it generate or appropriate?

We encounter here a deep problem of the human sciences that must be addressed before we proceed. (I say "we," in spite of my justexpressed commitment to an existentialism of the individual subject, because I am neither megalomaniac nor solipsistic - I accept as a practical matter the existence of other minds, other existential centers, although I cannot begin my inquiry from any standpoint but my own.) Whereas the natural structures lend themselves, naturally enough, to a natural-scientific account - anatomical, developmental, behaviorist intentional structures need a human-scientific account. What these

${ }^{6}$ I remember a talk at Columbia in which Monique Wittig was commenting on the impossibility of writing as a French woman in such a way as to hide gender. I asked her in the question period why she didn't just try it, referring to herself as "surpris" or "soumis" instead of "surprise" or "soumise." She gave, in effect, something like the argument about derivative costs that I have just outlined. While the question period went on it dawned on me what unfortunate examples I had chosen to illustrate an argument in a feminist context - taken by surprise, placed in submission. So at the reception afterwards I apologized for my insensitivity. Her reply was brilliant: with a smile she said gently "je serais surprise d'être soumise." 
accounts have to provide, as we have seen, is object-constancy across knowing subjects, which is simple enough for anatomy and (overt) behavior, but much harder for emotions and the other intentional structures we shall be encountering. The difficulty that arises is this: if I as an individual subject intend an object $X$, how can I communicate this to another subject? If I make the effort, and another subject now claims to intend the same object $X$, how can either of us know that it is in fact the same? The (assumed) perceptual constancy of physical objects is of less help here than in the natural sciences; it is of some help, because one obvious approach is to refer to bodily manifestations of emotion, for example, and the world is full of artifacts (books, images, articulate sounds) that can function as points of reference, but as stressed earlier the physical objects as such are never the point in the human sciences.

To this difficulty there is no definitive theoretical solution. The existential subject is isolated. But in fact the situation is at bottom very similar to the situation in the natural sciences. I qualified the perceptual constancy of physical objects above as "assumed," and that is because the existence even of the external world can in the end be only hypothetical - it falls under the "realist hypothesis" I discussed earlier. But if it is not plausible to assume that intended objects have the independence of the real, it is plausible to assume that there are other existential subjects who may also be intending those objects or similar ones. So to the realist hypothesis in the natural sciences corresponds what I shall call the "cointentional hypothesis" in the human sciences: for any object I intend, it is possible that there is another subject who intends or has intended it along with me. We will never know if the match is exact, but especially in cases where the intentionality in question is laid over a physical structure there can be at least a prima facie assumption of similarity.

For example, as I write I am playing a recording of Bach; the disk on which it is recorded is one of an edition of many; it is fair to assume that at least some of the pleasure I experience in listening to it has been experienced by others. Could I ever know this? Well, why not? I meet someone and we are talking about classical music, she mentions this work, I ask if she knows this particular recording, she comments on the way the conductor (or the sound engineer!) manages the balance between solo and ensemble passages, or some such thing we're not in much doubt that we are co-intending the same object in memory. Could we be at cross-purposes and could this go on for ever? 
Theoretically yes, but practically we can come as close to mutual understanding as the time for conversation allows. And the great mediator in the development of the human sciences is not observation but discourse, not evidence but argument. We tell one another what we "have in mind," we compare notes, we refer to texts or performances etc., we object, we suggest other ways of parsing or conceptualizing, we try out variations - in short by a long process of what I call "mutual instruction under mutual criticism" we bring our intended structures into some sort of congruence. Shared over a population of workers in a given field this process provides the object-constancy across knowing subjects that the human sciences strive for.

Another long introduction, I am afraid, to the next installment of my commentary on de Beauvoir, or at least on de Beauvoir's topic. But this background is important as we approach the intentional structures of sexuality. Let me make some categorical distinctions similar to the ones I made at the beginning of the section on natural structures. I shall distinguish between personal, interpersonal, and social intentional structures, and then again, cutting across these, between imaginative and emergent intentional structures. This last opposition is meant to capture the contrast between structures that remain at the level of thought and those that are realized in behavior, a distinction which is as we shall see of some importance in the domain of sexuality.

What then are the intentional structures of sexuality at a personal level? The question may seem odd, because many people are so constrained by the social that they believe that personal and even interpersonal structures of sexuality must conform to social expectations. But we are assuming liberation from all that. And it seems to me that the mature individual, confronting the possibilities of his or her own sexuality in abstraction from learned norms, is very much in the position of Freud's infant with its polymorphous perversity. There seems to be no a priori limit to what the individual can imagine as a possibility of sexual experience or enjoyment. And at the moment some aspects of the culture, far from constraining the individual in these matters, facilitate the polymorphy and the perversity by the provision of texts and images on which the intentionalities in question can be overlaid and given a kind of satisfaction. I refer of course to the unprecedented magnitude, in production, distribution, and revenue, of the pornographic industry. For a large proportion of sexual activity at this stage remains - and what a relief that is! - at the level of 
imagination rather than emergent behavior. It consists, in a word, of fantasy. Now it is true that we are some way here from Le deuxième sexe, because the entrepreneurs and the consumers in this industry are overwhelmingly male. And yet de Beauvoir, although I think she accepts too readily the idea that prostitution is just the dark side of marriage, recognizes in her chapter on "Prostituées et hétaïres" the reality of the demand and the possibility that it may sometimes be satisfied without loss of dignity on the part of the women who provide the carnal, or in the present market the overwhelmingly visual, or sometimes even verbal, products that respond to that demand.

I do not wish to suggest that all sexual fantasy is to be dismissed as pornographic - indeed I suspect that only a small proportion of it relies on pornography and that the rest, when it does not cross over into emergent behavior (or even when it does, in private), is healthy enough. Nor do I wish to suggest that the pornographic industry is innocent - on the contrary it is often oppressive, exploitative, and violent. But de Beauvoir is able to give a level-headed account of these matters without a rush to moral judgment. She says little, as is to be expected, about male fantasies, but devotes sympathetic attention to the fantasy life of young girls, with their crushes on teen idols or young teachers or old and slightly ridiculous professors (LDS II:114). It is interesting to follow the development of her thought in this part of the book - the chapter on La jeune fille is followed by that on L'initiation sexuelle, with its horror stories of uninvited aggression; but sandwiched between this and the chapter on La femme mariée, with its horror stories of spousal abuse - both forms of horror leading characteristically to fear and frigidity - is a chapter on La lesbienne, full of gentleness and understanding.

In the chapters on initiation and marriage the woman is represented, by and large, as in the passive position; it is as if she is, like the young girl, alone with her sexuality, with the difference that whatever imaginative or dreamlike intentionalities she might have harbored have turned into nightmares. It is not that de Beauvoir denies the possibility of mutuality in heterosexual relations, but given the dominant position of the male, both in seduction and in the consummation of marriage, her project draws her to the asymmetries involved. With the lesbian, however, we move to the level of the genuinely interpersonal. I take her understanding of the lesbian relation to be paradigmatic of binary intentional structures outside the sanctions of society, and to set a promising example of what I earlier called "new 
proto-cultures in which, for example, the relations between women and men are newly configured." This is the one domain, de Beauvoir thinks, in which genuine openness and frankness are possible. In this remarkable passage she describes what I take to be an ideal relation between friends:

... certaines circonstances donnent à ces liaisons des caractères singuliers. Elle ne sont pas consacrées par une institution ou par les coutumes, ni réglées par des conventions: elles se vivent de ce fait avec plus de sincérité. ... [A]uprès d'une amie elle ne parade pas, elle n'a pas à feindre, elles sont trop semblables de ne pas se montrer à découvert. Cette similitude engendre la plus totale intimité. L'érotisme souvent n'a qu'une assez petite part dans ces unions; la volupté a un caractère moins foudroyant, moins vertigineux qu'entre l'homme et la femme .... (LDS II:212-213).

The friends in this case are two women; in the middle of the passage de Beauvoir explains why it wouldn't work between men and women:

Homme et femme - fussent-ils époux - sont plus ou moins en représentation l'un devant l'autre, et surtout la femme à qui le mâle impose toujours quelque consigne ... jamais, en présence du mari et de l'amant, elle ne se sent tout à fait elle-même .... (LDS II:212)

While this may well have been true in 1949, especially in France, we need not take it as essentially true. Even if, as de Beauvoir says in another place, "En France, en particulier, la tradition antiféministe est si tenace qu'un homme croirait déchoir en participant à des tâches naguère réservées aux femmes," that is probably no longer as true as it was, and there are now plenty of men in many parts of the world who have moved beyond the clichés of gender assignment in the domestic sphere and are increasingly doing so in the interpersonal sphere as well.

Interpersonal, imaginative, intentional structures of sexuality can be seen, then, as an extension of the personal - they too have the freedom of the polymorphous-perverse, and this freedom carries over to some degree when the imaginative becomes the emergent and is enacted in real situations. External constraints come into play, from conflicts that arise because of the need for commitment to risks that may be run 
when fantasy becomes reality and the ideal lightness and purity of imagined relations is weighed down by the materiality of bodies and the risks of disease, etc., but the point here is that these structures need not conform to imposed social expectations. Until relatively recently those expectations were imposed repressively from without - there were intrusive regulations governing homosexual and even non-standard heterosexual relations - but there is now an increasing tendency to accept that what is done in private between consenting adults is to be shielded from legal and even social criticism. Even at the height of public disapproval it was often possible for homosexuals to manage their own private lives - de Beauvoir has a touching vignette of a lesbian couple of whom she says "il semble qu'elles aient su se créer en marge du monde un paisible éden" (LDS II:213). This was no doubt easier for women than for men - it is notorious that in British law there were no sanctions against female homosexuality because the males who drew it up could not believe that their idealized women could stoop to such a condition. All that seems now unacceptably intolerant and benighted. What I am suggesting is that the makeup of such interpersonal structures of sexuality, of which the primary example is the couple, is quite irrelevant to their standing - homosexual or heterosexual, all are free to create "en marge du monde" the space they need for the mutual exploration of erotic possibilities.

Following this line of thought to its logical next step suggests an eventual weakening of the power of the social and even the legal, and the opening up of a free space in which it would not matter who was male and who female - in which, while the moral constraints and restraints that apply because of personal commitments to others would retain their full force, no such limitations would derive from gender alone. We might think of this situation as one in which everyone is "en marge du monde" and the world at whose margins all the action is becomes less and less central and dominant. What then would become of the social intentional structures of sexuality? These exist primarily in the form of rules, culturally instructed since childhood, that insure (often uncritical) adherence to social norms. Authentic sexuality, de Beauvoir seems to say, is - in its erotic dimension at least - always at odds with such norms:

... l'érotisme implique une revendication de l'instant contre le temps, de l'individu contre la collectivité; il affirme la séparation contre la communication; il est rebelle à toute réglementation; il contient un principe hostile à la société. 
Jamais les moeurs ne sont pliées à la rigueur des institutions et des lois: c'est contre elles que l'amour s'est de tout temps affirmé (LDS I:305).

Society being what it is, it would be impossible to eliminate learned rules, but their role might change. The social structures might be so constructed as to protect the liberty of the interpersonal ones, serving less to determine than to monitor those structures, and in particular watching over the welfare of those potentially at risk from them. Their primary care would be for children: society, and the law, have no business intruding into my sexual life when this involves only consenting adults, but if a new life results they are entitled to require that I accept and fulfill certain obligations to that new life. Ideally of course no such life would come into being except as wanted and welcomed and provided for, but it is unrealistic to expect, from individuals driven by desire, the Utopian foresight and restraint that would be required for this ideal to be realized. Second only to this concern would be the continuing protection of, and redress for, those individuals - especially women - discriminated against on the grounds of gender.

I thus arrive, indirectly and belatedly, at what for many feminists, including de Beauvoir, is the central concern of feminism: the injustice and inequality of the distribution of power and opportunity as between the sexes. The virtue of the approach I have taken is, I think, to show that these things do not arise from an impartial consideration of the sexual constitution or the sexual projects of free individuals but must have their roots elsewhere. De Beauvoir is too ready, perhaps, to concede their power and to accept the situation into which women are placed by it. She writes, for example, “... il est demandé à la femme pour accomplir sa féminité de se faire objet et proie, c'est-à-dire de renoncer à ses revendications de sujet souverain. C'est ce conflit qui caractérise singulièrement la situation de la femme affranchie" (LDS II:600). But from whom does this demand come? The problem surely lies - and with this she would agree - with those who make the demand rather than with those of whom it is made. It is a man's problem, not a woman's problem:

... toute l'histoire des femmes a été faite par les hommes. De même qu'en Amérique il n'y a pas de problème noir mais un problème blanc; de même que "l'antisémitisme n'est pas un problème juif: c'est notre problème"; ainsi le problème de la femme a toujours été un problème d'hommes (LDS I:221). 
Not that this is much comfort to the woman who feels herself the object of hostility, dismissal or aggression, but at least it removes the issue of sexuality as such from the center of the stage. No doubt the sexual identity of the male is implicated in his attitudes, but this is a question more often of a threat to his sexuality than of a desire to fulfill it. The problem is more cognitive than affective. Many men have been brought up - often, it must be said, by women - to believe that women cannot or should not do traditionally masculine things or fill traditionally masculine roles. De Beauvoir is right to assimilate the issue to racism and antisemitism, because in all three cases the cognitive error is the same. It consists in attributing to individual members of a group accidental properties unrelated to the defining properties that make them members of the group in the first place. Even if (and this is not something to be assumed lightly!) there is a statistical likelihood that members of the group will have the accidental property in question, nothing follows in that respect about a given individual, and it is discriminatory to act as if it does.

So it is just a mistake to conclude, from the fact that a given adult member of the human race is female, that anything else whatever is true of her in the absence of further evidence - it is even a mistake, some gender theorists would claim, to conclude that she is a woman. This would follow from de Beauvoir's celebrated formulation in the opening sentence of the second volume of Le deuxième sexe: "On ne naît pas femme: on le devient" (LDS II:13). It is worth noting in passing that she says exactly the same thing about genius in the first volume: “... on ne naît pas génie: on le devient ...." (LDS I:226). What follows in each case is significant: if female, one need not become a woman ("[a]ucun destin biologique, psychique, économique ne définit pas la figure que revêt au sein de la société la femelle humaine"), but as things stand in 1949 one cannot, if female, become a genius ("la condition féminine a rendu jusqu'à présent ce devenir impossible"). Everything hinges on the prevailing conditions; and the prevailing conditions have to change.

I said earlier, in suggesting that de Beauvoir's model of the lesbian relation might be a paradigm for liberated interpersonal relations between men and women, that "plenty of men ... have moved beyond the clichés of gender assignment." Not enough yet, perhaps, but the trend is worth encouraging. Does this mean that men need to be more like women? No, de Beauvoir would say - no more than the reverse. I return in closing, then, to the vexed question of brotherhood. 
I am inclined at this point to say that sisterhood would do as well, that both concepts can carry the universal as well as the particular, that men should be able to enter a female world without feeling a threat to their masculinity just as women should be able to enter a male world without losing their femininity. Masculinity and femininity are not essential attributes, they are assumed, and either sex may feel comfortable in either garb - or, to put it another way, it is no one's business to make anyone else uncomfortable whatever choice he or she may make in this respect. The foundation for harmony and equity is an acknowledgment of ambiguity. The trouble up to now, as de Beauvoir sees it, is that both men and women tend to think of their own sexuality as honorable, that of the other sex as abject:

...au lieu de vivre l'ambiguité de sa condition, chacun s'efforce d'en faire supporter par l'autre l'abjection et de s'en réserver l'honneur. Si cependant tous deux l'assumaient avec une lucide modestie, corrélative d'une authentique orgueil, ils se reconnaîtraient comme des semblables et vivraient en amitié le drame érotique (LDS II:658).

To assume one's ambiguity with lucid modesty and authentic pride takes nothing away from the drama of the erotic. De Beauvoir might well have ended her book here. It is her great merit to have been able to see the eventually desirable community of interest of women and men not merely under the sign of brotherhood but under that of friendship.

The George Washington University

Peter Caws

\section{Works Cited}

Beauvoir, Simone de. Le deuxième sexe. 2 vols. Paris: Gallimard, 1949.

---. The Second Sex. 1953. Trans. and Ed. H. M. Parshley. New York: Vintage, 1974.

Held, Virginia. Feminist Morality: Transforming Culture, Society, and Politics. Chicago: University of Chicago Press, 1993.

Kuykendall, Eleanor. "Simone de Beauvoir and Two Kinds of Ambivalence in Action." The Thinking Muse. Eds. Iris Young and Jeffner Allen. Bloomington: University of Indiana Press, 1989. 35-50.

Olshaker, Bennett, M.D. The Child as a Work of Art. Washington: Marko Books, 1975. 